\title{
A COMPARATIVE STUDY OF EFFECTS OF STORAGE ON BASIC NUTRITIONAL COMPOSITION OF TWO MAJOR EDIBLE DIOSCOREA DUMENTORUM VARIETIES
}

O. I. OJO AND J. O. OJO

(Received 11, February 2008; Revision Accepted 21, July 2009)

\begin{abstract}
The proximate analysis comprising the carbohydrate, crude protein, crude fibre, ash and moisture contents, and the minerals analysis of two major edible varieties of Dioscorea dumentorum (Esuru), commonly consumed in Ekiti State, Nigeria were estimated after a period of storage using standard chemical methods. The crude protein percentage for stored yellow and white varieties are 3.13 and 2.50 respectively. This is contrary to that of fresh varieties whose crude protein percentages for the yellow and white varieties are 8.24 and 5.44 respectively. The results reveal a significant decrease in protein content in stored Discorea dumentorum varieties compared with previous work on fresh varieties. The crude fat content for the stored yellow and white varieties are 6.07 and $6.88 \%$ respectively, while the ash content and the crude fibre contents for the stored yellow and white varieties are $2.80,2.53$ and 1.73 and $1.79 \%$ respectively. The carbohydrate contents of the two varieties are 26.97 and $21.33 \%$ in the same order. The presence of important minerals like iron, magnesium, phosphorus, calcium, and zinc at a very high level showed that bitter yam would find some useful application in the food and pharmaceutical industries.
\end{abstract}

KEYWORDS: Nutritional composition, Dioscorea dumentorum, storage, proximate

\section{INTRODUCTION}

Yams are classified generally under the genus discorea, family discoreaceae and under discorcales. The yams are the most important food cereals. (Coursey, 1967; Mc Anuff, 2002). They also form an important food source in other tropical countries including East Africa, the Carribeans, South Africa etc.

Bitter yam (Discorea dumentorum), is one of the most important species of discorea. Bitter yam grows well in well drained, fertile and high textured soil with an annual rainfall ranging between 10 and 70 inches. Automatically, the leaves resemble other flowering plants with stomata occurring only on the lower surface. The local names in Nigeria are Kosanrogo, Ona and Esuru in Hausa, Ibo and Yoruba respectively. Other common names of the yam are three-leaved yam, bitter yam and cluster yam. There are four common varieties of bitter yam of which two are edible, while the other two are toxic. Yellowish- white is toxic to animal alone and the white toxic is toxic to both animal and man.

Bitter yam like any other yam tuber is a very good source of energy and carbohydrate when consumed. It is also used in the production of local beer from detoxified variety (Kay, 1973). The yellow variety of bitter yam is the most preferred of the edible varieties. Despite the importance of the bitter yam, none of the edible varieties can be pounded, unlike many other varieties of yam tuber such as $D$. Rotundata. The toxic varieties are not edible but they are commonly used for pharmaceutical or medicinal purposes by African and Asian people (Mc Anuff et al, 2003). Its has been shown to contain dihydrodiscorine isoclines, a heart stimulant (Bevan and Hirst, 1985) and dioscorcoretine, a hypoglycemic agent (Iwu et al, 1990).

Akubue and Mitta (1982) reported the use of discorea dumentorum tuber by Nigerian herbalists for the treatments of clinical diabetes. Despite the wide consumption of bitter yam as an important source of dietary energy, only limited studies have been carried out on the comparative studies of effect of storage on nutritional values and mineral analyses of two edible varieties of bitter yam.

\section{MATERIALS AND METHOD}

Two edible varieties of bitter yam were obtained from kings market, Ikere-Ekiti, Ekiti State, Nigeria, stored for 6 weeks, and later peeled, and chipped. These samples were sun dried, and later oven dried at $50^{\circ} \mathrm{C}$ to obtain a constant dry weight. They were subsequently ground into fine powder for analysis. All chemicals used for the analysis were of analytical grades.

The proximate composition, moisture, crude fat, and crude fibre were determined by methods of Association of Official Analytical Chemist, (AOAC,1990). Protein was determined using the method described by Pearson (1976) and the percentage nitrogen converted to crude protein by multiplying by 6.25 . The amount of carbohydrate contained was determined by difference.

Mineral analysis of the sample were carried out using solutions obtained from the first dry ashing of the yam flour at $550^{\circ} \mathrm{C}$ and subsequently the ashes were dissolved in $25 \mathrm{ml}$ flask using deionised water; $\mathrm{Mn}, \mathrm{Fe}$, $\mathrm{Zn}, \mathrm{Pb}, \mathrm{Cu}, \mathrm{Cd}, \mathrm{Mg}$ and $\mathrm{Ca}$ were determined by means

O. I. OJO, Chemistry Department, College of Education, Ikere-Ekiti

J. O. OJO, Chemistry Department, Federal University of Technology, Akure. 
of atomic absorption spectrophotometer (Pyunicam Spa Cambridge UK), while $\mathrm{Na}$ was determined using flame photometer (Corning 405).

The phosphorus content was determined colorimetrically on spectronic 20 (Gallenkanp London, U.K) using the phosphovanado molybdate method (AOAC, 1990).

\section{RESULTS AND DISCUSION}

Table 1: Proximate Composition of Two Major Edible Varieties of Bitter Yam (Dioscorea dumetorum) on Dry weight basis.

\begin{tabular}{|c|c|c|c|c|c|c|}
\hline \multicolumn{7}{|c|}{ \% Composition } \\
\hline $\begin{array}{l}\text { Bitter Yam } \\
\text { Varieties }\end{array}$ & $\begin{array}{l}\text { Moisture } \\
\text { Contents }\end{array}$ & $\begin{array}{l}\text { Ash } \\
\text { Contents }\end{array}$ & $\begin{array}{l}\text { Crude } \\
\text { Fat }\end{array}$ & $\begin{array}{l}\text { Crude } \\
\text { Fibre }\end{array}$ & $\begin{array}{l}\text { Crude } \\
\text { Protein }\end{array}$ & Carbohydrate \\
\hline Yellow & 59.30 & 2.80 & 6.07 & 1.73 & 3.13 & 26.97 \\
\hline White & 64.97 & 2.53 & 6.88 & 1.79 & 2.5 & 21.33 \\
\hline $\mathbf{X}$ & 62.135 & 2.665 & 6.475 & 1.76 & 2.815 & 24.15 \\
\hline S.D & 4.009295 & 0.190919 & 0.572756 & 0.042426 & 0.445477 & 3.988082 \\
\hline
\end{tabular}

The result of proximate composition shows that the crude protein for varieties $A$ and $B$ are $3.13 \%$ and $2.50 \%$ respectively. The yellow edible varieties $(A)$ has the higher percentage of crude protein value, which agrees with the trend $8.24 \%$ for $A$, yellow variety and $5.44 \%$ for $B$, white variety, observed by Ogunlade et al (2006). The drastic reduction in the crude protein percentage generally was as result of the storage period of which high percentage of crude protein had been used up for re- development.
Table 1 shows the proximate composition of the two major edible of bitter yam (Dioscorea dumetorum). The moisture content of the stored bitter yam are 59.30 $\%$ and $64.97 \%$ for varieties $A$ and $B$ respectively, which is lower than the values 70.87 and $70.07 \%$ respectively reported by Ogunlade et al (2006). The general reduction in percentage of the moisture content in the $A$ and $B$ varieties is due to loss of water during storage.

Table 2: Mineral Composition of Two major Edible Bitter Yam (mg/100g)

\begin{tabular}{|c|c|c|c|c|c|c|c|c|c|}
\hline $\begin{array}{l}\text { Bitter } \\
\text { Yam } \\
\text { Varieties }\end{array}$ & $\mathbf{P}$ & $\mathrm{Na}$ & $\mathrm{Mg}$ & $\mathrm{Ca}$ & $\mathrm{Fe}$ & K & Mn & $\mathrm{Pb}$ & Cd \\
\hline Yellow & 131.67 & 94.17 & 20.51 & 29.21 & 5.91 & 30.31 & ND & ND & $\overline{N D}$ \\
\hline White & 88.68 & 117.39 & 29.37 & 30.56 & 4.01 & 39.14 & ND & ND & ND \\
\hline$X$ & 110.175 & 105.78 & 24.94 & 29.885 & 4.96 & 34.725 & ND & ND & ND \\
\hline S.D & 30.39852 & 16.41902 & 6.264966 & 0.954594 & 1.343503 & 6.243753 & ND & ND & ND \\
\hline
\end{tabular}

$$
\begin{aligned}
& \text { ND }=\text { Not Detected } \\
& X=\text { Mean } \\
& \text { SD }=\text { standard Deviation }
\end{aligned}
$$

The crude fat content for the varieties $A$ and $E$ are $6.07 \%$ and $6.88 \%$ respectively, which is comparable with the $1.60 \%$ and $1.70 \%$ obtained by Ogunlade et al (2006) for the species and in which the white variety has the highest value.

The ash contents are $2.80 \%$ and $2.53 \%$ respectively for varieties $A$ and $B$, the crude fibre content values are $1.73 \%$ and $1.79 \%$; the carbohydrate content of the varieties $A$ and $B$ are $26.97 \%$ and $21.33 \%$ respectively. 
The result of the mineral composition of the two edible varieties of bitter yam is presented in Table 2 . The white edible variety has the highest value for sodium (117.39mg/100g), magnesium (29.37mg/100g), calcium $(30.56 \mathrm{mg} / 100 \mathrm{~g})$ and potassium $(39.14 \mathrm{mg} / 100 \mathrm{~g})$. The yellow edible variety has the highest value for phosphorus $(131.67 \mathrm{mg} / 100 \mathrm{~g})$ and iron $(5.91 \mathrm{mg} / 100 \mathrm{~g})$. The level of the mineral constituent of the stored bitter yam varieties were higher than the fresh type reported by Ogunlade et al (2006) respectively as follows:

For the stored yellow and white bitter yam respectively, $\mathrm{Fe}$ has the values of $5.91 \mathrm{mg} / 100 \mathrm{~g}$ and $4.01 \mathrm{mg} / \mathrm{l00 \textrm {g }}$ while for the fresh type the values are 0.45 $\mathrm{mg} / \mathrm{l00g}$ and $1.52 \mathrm{mg} / \mathrm{l00g}$ respectively.

The values for $\mathrm{Na}$ in the stored yellow and white varieties are $94.17 \mathrm{mg} / \mathrm{l00g}$ and $117.39 \mathrm{mg} / \mathrm{l00g}$ respectively, while that of the fresh type reported by Ogunlade et al (2006) are $54.99 \mathrm{mg} / \mathrm{l00g}$ and 98.75 $\mathrm{mg} / \mathrm{l00g}$ respectively. The high increase in concentration of the mineral composition of the stored bitter yam varieties is due to the loss of water into the atmosphere during the storage period.

Manganese, and some heavy metals like lead, and cadmium, were not detected in any of the varieties which agrees with the results obtained by Ogunlade et al (2006) for fresh bitter yam varieties.

The variation in the mineral composition in the varieties might depend on the chemical composition of the soil upon which the bitter yam was planted, because the yellow and the white yams were grown in deferent soils.

\section{CONCLUSION}

The result shows that yellow bitter yam is relatively higher in crude protein than the white varieties, and that protein level of stored bitter yam is less than that of fresh type studied by Ogunlade et al (2006).

The result also shows that bitter yam contains most of the important minerals such as iron, magnesium, phosphorus, calcium, and zinc, even at a very high level when stored for some time, and therefore the edible varieties would find some useful applications in the food and pharmaceutical industries.

\section{REFERENCES:}

AOAC, 1990. Official Method of Analysis $15^{\text {th }}$ Ed Association of official Analytical chemists Washington D.C.
Bevan, C. W. L and Hirst, J., 1985. A Convulsant Alkaloid of Dioscorea dumetorum, Chem Ind 4 : 103.

Coursey, D. G., 1967 Yams, an account ot the nature, origins, cultivation, and utilization of the useful members of Dioscoreaceae. Longman, London: pp230.

Iwu. M. M., Okunji, C. O., Akah, P, Tempesta, M. S., and Corley, D. 1990. Dioscoretine: The hypoglycaemic principle of Dioscorea dumetorum. Planta Med, 56: 119-120.

Kay. D. E., 1973. Root Crops. TPI Crop and Product Digest Overseas Development Agency. London. pp 102.

McAnuff, M. A., Omoruyi, F.O., Morrison, E. Y.A. and Asemola, H.N., 2002. Plasma and liver lipid distributions in streptozotocin induced diabetic rats fed sapogenin extract of the Jamaican bitter yam (Dioscorea polygonoides).Nutrition Research 22: $1427-1434$.

McAnuff. M. A., Harding, W. W., Omoruyi F. O., Jacobs H., Morrison, E. Y. and Asemota, H. N., 2003. Alterations in intestinal morphology of streptozotocin induced diabetic rats fed Jamaican bitter yam (Dioscorea polygonoides) steroidal sapogenin extract. Nutrition Research 23: 1569-1577.

McAnuff. M. A., Harding, W. W., Omoruyi F. O., Jacobs H., Morrison, E. Y. and Asemota, H. N., 2005. Hypoglycemic effects of steroidal sapogenins isolated from! Jamaican bitter yam, Dioscorea polygonoides. Food and Chemical toxicology 43: 1667-1672.

Ogunlade Y., Owojuyigbe O.S., and Azees M.A., 2006. The Chemical Composition and Functional properties of fresh varieties of bitter yam (Dioscorea dumentorum) Bulletin of Pure and Applied Sciences 25c: 7-12.

Person, D., 1976. Chemical Analysis of Food, $7^{\text {th }}$ Ed. Churchill, London pp 62. 